\title{
- Cation-Dependent Self-assembly of Vanadium Polyoxoniobates
}

\author{
2 Pavel A. Abramov, ${ }^{* \dagger, \ddagger(0)}$ Anastasiia T. Davletgildeeva, ${ }^{\dagger, \dagger}$ Nikolay K. Moroz, ${ }^{\dagger}$ Nikolay B. Kompankov, ${ }^{\dagger}$ \\ ${ }_{3}$ Beatrix Santiago-Schübel, ${ }^{\S}$ and Maxim N. Sokolov ${ }^{\dagger, \ddagger}$ \\ $4{ }^{\dagger}$ Nikolaev Institute of Inorganic Chemistry SB RAS, Novosibirsk, Russia 630090 \\ $5{ }^{*}$ Novosibirsk State University, Novosibirsk, Russia 630090 \\ $6{ }^{\S}$ Central Institute for Engineering, Electronics and Analytics - ZEA-3, Forschungszentrum Jülich, 52425, Jülich, Germany
}

\section{S Supporting Information}
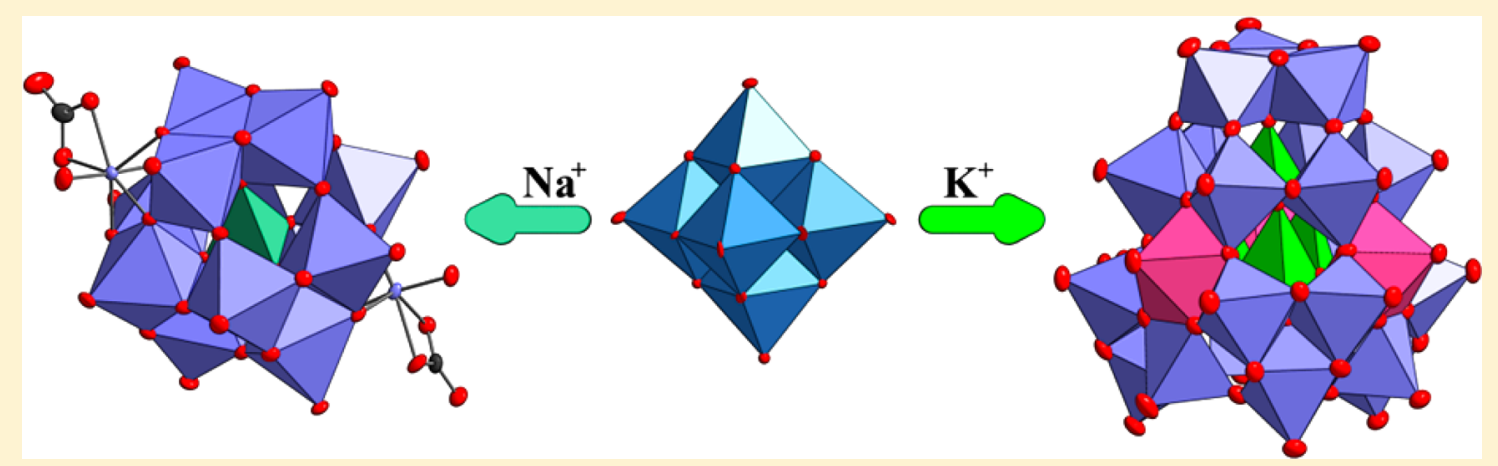

\begin{abstract}
8 ABSTRACT: Reaction of $\mathrm{Na}_{7} \mathrm{H}\left[\mathrm{Nb}_{6} \mathrm{O}_{19}\right] \cdot 15 \mathrm{H}_{2} \mathrm{O}$ with $\mathrm{NaVO}_{3} \cdot 2 \mathrm{H}_{2} \mathrm{O}$ at $220{ }^{\circ} \mathrm{C}$ in the presence of $\mathrm{NaHCO}_{3}$ gives new bicapped $\alpha$-Keggin vanadododecaniobate $\left[\mathrm{VNb}_{12} \mathrm{O}_{40}\left\{\mathrm{NbO}\left(\mathrm{CO}_{3}\right)_{2}\right]^{13-}\right.$, isolated and structurally characterized as $\mathrm{Na}_{9} \mathrm{H}_{4}\left[\mathrm{VNb}_{12} \mathrm{O}_{40^{-}}\right.$ $\left.\left\{\mathrm{NbO}\left(\mathrm{CO}_{3}\right)\right\}_{2}\right] \cdot 37 \mathrm{H}_{2} \mathrm{O}(\mathbf{1})$. According to ${ }^{51} \mathrm{~V}$ NMR and ESI-MS data, this anion equilibrates in solution with $\left[\mathrm{VNb}_{12} \mathrm{O}_{40}\right]^{15-}$ and oligomeric species that result from dissociation of the $\left\{\mathrm{NbO}\left(\mathrm{CO}_{3}\right)\right\}^{+}$fragments. In the presence of potassium, the same reaction gives $\left[\mathrm{V}_{x} \mathrm{Nb}_{24} \mathrm{O}_{76}\right]^{n-}(x=4, n=12(2 \mathrm{a}) ; x=3, n=17(2 \mathbf{b}))$. The anions with $x=3$ and 4 cocrystallize together, but exist as separate entities both in solid and in solution according to ${ }^{51} \mathrm{~V}$ MASS NMR and ESI-MS data.
\end{abstract}

15 The chemistry of niobium polyoxocomplexes (polyoxoniobates, $16 \mathrm{PONb})$ is a challenging area of polyoxometalate chemistry, 17 experiencing a spectacular renaissance. ${ }^{1}$ Besides unique solution 18 behavior defined by extraordinary strong cation association, the $19 \mathrm{PONb}$ show photocatalytic activity in water splitting, which 20 constitutes a hot topic in modern chemistry. ${ }^{3}$ One of the 21 problems in the chemistry of $\mathrm{PONb}$ is finding conditions for 22 producing of larger, nanosized polyoxocomplexes-nanosized 23 models of $\mathrm{Nb}_{2} \mathrm{O}_{5}$. The most common way to achieve this is 24 thermal induction of the $\mathrm{PONb}$ aggregation from hexaniobates $25\left[\mathrm{Nb}_{6} \mathrm{O}_{19}\right]^{8-}$ at different $\mathrm{pHs}$. In this way, transient $\left\{\mathrm{Nb}_{7} \mathrm{O}_{22}\right\}^{9-}$ 26 building blocks are generated, which combine into trimeric $27\left[\mathrm{Nb}_{24} \mathrm{O}_{72}\right]^{14-}$ or larger aggregates. ${ }^{4}$ Cronin et al. studied this 28 aggregation in solutions of $\mathrm{K}_{7} \mathrm{H}\left[\mathrm{Nb}_{6} \mathrm{O}_{19}\right] \cdot 13 \mathrm{H}_{2} \mathrm{O}$ at $200{ }^{\circ} \mathrm{C}$ and 29 were able to detect the formation of larger $\left\{\mathrm{Nb}_{10}\right\},\left\{\mathrm{Nb}_{20}\right\}$, and $30\left\{\mathrm{Nb}_{27}\right\}$ isopolyniobates, and isolate $\left[\mathrm{HNb}_{27} \mathrm{O}_{76}\right]^{16-}$ and $31\left[\mathrm{H}_{10} \mathrm{Nb}_{31} \mathrm{O}_{93}\left(\mathrm{CO}_{3}\right)\right]^{23-5}$. Both complexes contain a rare 32 pentagonal $\left\{(\mathrm{Nb}) \mathrm{Nb}_{5}\right\}$ building block, which had been 33 observed only in $\mathrm{Nb}$ oxides. ${ }^{6}$ The existence of such a unit 34 indicates a link to the chemistry of giant polymolybdates, where 35 the pentagonal $\left\{(\mathrm{Mo}) \mathrm{Mo}_{5}\right\}$ building blocks steer aggregation 36 toward spherical and wheel-shaped nanoscale POMs like Mo 37 blues or keplerates. ${ }^{7}$ In the structure of $\left[\mathrm{HNb}_{27} \mathrm{O}_{76}\right]^{16-}$, there 38 are four tetrahedral cavities inside the backbone, and a large crown-ether like cavity in the bottom part. This means that 39 heteroatoms with stable tetrahedral arrangements $\left(\mathrm{V}^{\mathrm{V}}, \mathrm{P}^{\mathrm{V}}, \mathrm{As}^{\mathrm{V}}\right){ }_{40}$ could stabilize such structures. Vanadium and phosphorus are 41 the most suitable to prove this suggestion experimentally, both 42 from their smaller size and amenability to NMR studies. In this 43 contribution, we report hydrothermal rearrangements of 44 sodium and potassium hexaniobates in the presence of 45 $\mathrm{NaVO}_{3}$ as vanadium source, leading to vanadoniobates of two 46 distinct types.

\section{EXPERIMENTAL SECTION}

48

General Information. Starting hexaniobates $\mathrm{A}_{7} \mathrm{H}\left[\mathrm{Nb}_{6} \mathrm{O}_{19}\right] \cdot n \mathrm{H}_{2} \mathrm{O} 49$ ( $\mathrm{A}=\mathrm{Na}, n=15 ; \mathrm{A}=\mathrm{K}, n=13$ ) were prepared according to the 50 published procedures. ${ }^{8}$ TG experiments were done on a NETZSCH 51 TG $209 \mathrm{~F} 1$ device in an $\mathrm{Al}_{2} \mathrm{O}_{3}$ crucible by heating a sample from 22 to 52 $300{ }^{\circ} \mathrm{C}$ with a $10{ }^{\circ} \mathrm{C}$ gradient. IR spectra $\left(4000-400 \mathrm{~cm}^{-1}\right)$ were 53 recorded on a Vertex 80 spectrometer. Raman spectra (60-4000 54 $\mathrm{cm}^{-1}$ ) were obtained on a Triplemate spectrometer (Spex, USA) 55 equipped with a multichannel detector LN-1340 PB (Princeton 56 Instruments, USA). EDX analysis was performed on a HITACHI TM 57 3000 Tabletop Microscope. Elemental analysis for $\mathbf{1}$ and $\mathbf{2}$ was carried 58 out on a high-resolution spectrometer iCAP-6500 (Thermo Scientific) 59 with a cyclone type spray chamber and "SeaSpray" nebulizer. NMR 60

Received: August 31, 2016 
61 spectra were run on a Bruker Avance III 500 spectrometer at room 62 temperature with addition of a very small amount of $\mathrm{D}_{2} \mathrm{O}$ to the 63 sample aqueous solutions. The ${ }^{51} \mathrm{~V}$ chemical shift was referenced to 64 external $\mathrm{VOCl}_{3}(\delta=0 \mathrm{ppm})$ as standard. The total sweep covered 65 from -1000 to $0 \mathrm{ppm}$. Solid state NMR experiments were run on a 66 Bruker Avance III 500 spectrometer at $5-15 \mathrm{kHz}$.

67 Synthesis of $\mathrm{Na}_{9} \mathrm{H}_{4}\left[\mathrm{VNb}_{12} \mathrm{O}_{40}\left\{\mathrm{NbO}\left(\mathrm{CO}_{3}\right)\right\}_{2}\right] \cdot 37 \mathrm{H}_{2} \mathrm{O}$ (1). Solid $68 \mathrm{Na}_{7} \mathrm{H}\left[\mathrm{Nb}_{6} \mathrm{O}_{19}\right] \cdot 15 \mathrm{H}_{2} \mathrm{O}(0.400 \mathrm{~g}, 0.31 \mathrm{mmol}), \mathrm{NaVO}_{3} \cdot 2 \mathrm{H}_{2} \mathrm{O}(0.046 \mathrm{~g}$, $690.31 \mathrm{mmol})$, and $\mathrm{NaHCO}_{3}(0.150 \mathrm{~g}, 1.79 \mathrm{mmol})$ were dissolved in 10 $70 \mathrm{~mL}$ of distilled water upon heating and stirring $(\mathrm{pH} 13.0)$. The 71 solution was transferred into a stainless steel autoclave (the volume of 72 the Teflon cartridge was $30 \mathrm{~mL}$ ), and the mixture was kept at $220{ }^{\circ} \mathrm{C}$

73 for $18 \mathrm{~h}$. After cooling, a colorless precipitate was filtered off (final pH 74 was 10.3), and the filtrate was reduced in volume by heating at $90^{\circ} \mathrm{C}$ 75 to $3 \mathrm{~mL}$. The concentrated solution was placed into a vial for slow 76 evaporation. Rhombohedral colorless crystals were collected by 77 filtration, rinsed with deionized water, and dried in air. Recrystalliza78 tion from deionized water gave colorless crystals of 1 . Yield $0.131 \mathrm{~g}$ 79 (13\%) based on niobium. EDX: atomic ratio Na:Nb:V - 9.1:13.8:1.0. 80 ICP-AES found $\mathrm{Na}, \mathrm{Nb}, \mathrm{V}(\%): 6.7,43.6,1.5$, calculated for 1: $\mathrm{Na}, \mathrm{Nb}$, $81 \mathrm{~V}(\%): 6.9,43.8,1.7 .{ }^{51} \mathrm{~V}$ NMR $\left(\mathrm{H}_{2} \mathrm{O}+\mathrm{D}_{2} \mathrm{O}\right.$, r.t., $\delta$, ppm): -481.3 ; $82-487.1 ;-492.8 ;-532.1 .{ }^{51} \mathrm{~V}$ MASS NMR: $-530 \mathrm{ppm} .{ }^{13} \mathrm{C}$ MASS 83 NMR: -166 ppm. IR (KBr, $\nu, \mathrm{cm}^{-1}$ ): 3418 (s), 1604 (m), 1459 (m), $841340(\mathrm{~m}), 1053$ (w), 874 (s), 800 (s), 656 (s), 581 (s), 461 (s), 401 $85(\mathrm{~s})$. Raman $\left(\nu, \mathrm{cm}^{-1}\right): 1065(\mathrm{~m}), 913(\mathrm{vs}), 856(\mathrm{~s}), 368(\mathrm{~m}), 250(\mathrm{~m})$, $86215(\mathrm{~m})$. TGA: weight loss $13 \%$ corresponds to the removal of 30 87 water molecules.

88 Synthesis of 2, Containing Potassium Salts of $\left[\mathrm{Nb}_{24} \mathrm{O}_{76} \mathrm{~V}_{4}\right]^{12-}$ 89 (2a) and $\left[\mathrm{V}_{3} \mathrm{Nb}_{24} \mathrm{O}_{76}\right]^{17-}$ (2b). Solid $\mathrm{K}_{7} \mathrm{H}\left[\mathrm{Nb}_{6} \mathrm{O}_{19}\right] \cdot 13 \mathrm{H}_{2} \mathrm{O}(0.400 \mathrm{~g}$, $900.30 \mathrm{mmol}), \mathrm{NaVO}_{3} \cdot 2 \mathrm{H}_{2} \mathrm{O}(0.046 \mathrm{~g}, 0.31 \mathrm{mmol})$, and $\mathrm{NaHCO}_{3}$ $91(0.150 \mathrm{~g}, 1.79 \mathrm{mmol})$ were dissolved in $10 \mathrm{~mL}$ of water upon heating 92 and stirring $(\mathrm{pH}$ 13.0). The final solution was transferred into a 93 stainless steel autoclave ( $30 \mathrm{~mL}$ Teflon cartridge), and the mixture was 94 kept at $220{ }^{\circ} \mathrm{C}$ for $18 \mathrm{~h}$. After cooling, a colorless precipitate was 95 filtered off (final $\mathrm{pH}$ was 10.3), and the filtrate was reduced by heating 96 at $90{ }^{\circ} \mathrm{C}$ to $3 \mathrm{~mL}$ volume. This concentrated solution was placed into a 97 vial and left for crystallization. Overnight, hexagonal plate colorless 98 crystals appeared and were collected by filtration, rinsed with 99 deionized water, and dried in air. Repeated recrystallizations from 100 small amounts of deionized water produced hexagonal plates suitable 101 for X-ray analysis. Yield of $20.07 \mathrm{~g}$ (4\%) based on niobium. ${ }^{51} \mathrm{~V}$ NMR $102\left(\mathrm{H}_{2} \mathrm{O}+\mathrm{D}_{2} \mathrm{O}\right.$, r.t., $\delta$, ppm $):-532.5 .{ }^{51} \mathrm{~V}$ MASS NMR: $-532(\mathrm{~m})$. 103 Raman $\left(\nu, \mathrm{cm}^{-1}\right)$ : $1065(\mathrm{~m}), 935(\mathrm{vs}), 919(\mathrm{~s}), 907(\mathrm{~s}), 867(\mathrm{~m}), 647$ $104(\mathrm{~m}), 498(\mathrm{~m}), 360(\mathrm{~m}), 329(\mathrm{~m}), 244(\mathrm{~m}), 211(\mathrm{~m})$. TGA: weight loss $10516 \%$ that corresponds to removal of 42 water molecules. EDX: atomic 106 ratio $\mathrm{K}: \mathrm{Na}: \mathrm{Nb}: \mathrm{V}$ is $1.6: 2.3: 6.7: 1$. ICP-AES: found $\mathrm{K}, \mathrm{Na}, \mathrm{Nb}, \mathrm{V}(\%)$ : 107 4.4, 4.3, 46.2, 3.5, calculated for $\mathrm{K}_{6} \mathrm{Na}_{8.5}\left[\mathrm{Nb}_{24} \mathrm{~V}_{3.5} \mathrm{O}_{76}\right] \cdot 42 \mathrm{H}_{2} \mathrm{O}$ (as 0.5 / 1080.5 mixture of $\mathbf{2 a}$ and $\mathbf{2 b}) \mathrm{K}, \mathrm{Na}, \mathrm{Nb}, \mathrm{V}$ (\%): 4.9, 4.1, 46.4, 3.7.

109 Electrospray lonization Mass Spectrometry (ESI-MS). The 110 experiments were performed on a hybrid linear ion trap FTICR mass 111 spectrometer LTQ-FT (Thermo Fisher Scientific, Bremen, Germany) 112 equipped with a $7 \mathrm{~T}$ supra-conducting magnet by infusion. The mass 113 spectrometer was first tuned and calibrated in the negative mode 114 following the standard optimization procedure for all voltages and 115 settings. The complex was dissolved in $80 \% \mathrm{H}_{2} \mathrm{O}$, and $20 \%$ methanol 116 was added for ionization. The transfer capillary temperature was set at $117175{ }^{\circ} \mathrm{C}$. Mass spectra were recorded in full scan from 200 to $2000 \mathrm{Da}$ 118 with a resolution of 100.000 at $\mathrm{m} / z 400$. The data were processed with 119 the Xcalibur software version 2.1.

120 X-ray Diffraction. The diffraction data were collected at $150 \mathrm{~K}$ on 121 a Bruker Apex Duo (for $\mathbf{1}$ ) and on an Xcalibur (Agilent Technologies) 122 at $130 \mathrm{~K}$ (for 2 ) single crystal diffractometers with Mo K $\alpha$ radiation $(\lambda$ $123=0.71073 \AA$ ) by doing $\omega$ and $\varphi$ scans of narrow $\left(0.5^{\circ}\right)$ frames. The 124 structures were solved by direct methods and refined with full-matrix 125 least-squares treatment against $|F|^{2}$ in anisotropic approximation with 126 SHELX $2014 / 7^{9}$ in the ShelXle program. ${ }^{10}$ Absorption corrections 127 were applied empirically with SADABS ${ }^{11}$ and SCALE3 ABSPACK 128 programs (CrysAlisPro 1.171.38.41 (Rigaku OD, 2015)). Crystallo129 graphic data and refinement details for $\mathbf{1}$ and 2are listed in Table S1, 130 and main bond distances for $\mathbf{1}$ are listed in Table S2.
Crystals of $\mathbf{2}$ grow as aggregates of thin poorly diffracting hexagonal 131 plates, and the XRD data collection was done from a twinned crystal 132 that gave a mediocre $R$ value. Composition of $\mathbf{2}$ was assigned with the 133 help of EDX, TGA, and ESI-MS data.

Crystallographic data files for $\mathbf{1}$ and $\mathbf{2}$ have been deposited with 135 ICSD (Fachinformationszentrum Karlsruhe, 76344 Eggenstein-Leo- 136 poldshafen, Germany; e-mail: crysdata@fiz-karlsruhe.de) with num- 137 bers CSD 431897 (1), CSD 431896 (2).

\section{RESULTS AND DISCUSSION}

Synthesis and Structure of 1. Heating a mixture of 140 sodium metavanadate and sodium hexaniobate at $220{ }^{\circ} \mathrm{C} 141$ (initial $\mathrm{pH}$ 12) for $18 \mathrm{~h}$ produces a copious amorphous material 142 and a clear colorless solution, which contains two distinct types 143 of vanadates, according to ${ }^{51} \mathrm{~V}$ NMR data-mainly the cyclic 144 tetravanadate $\left[\mathrm{V}_{4} \mathrm{O}_{12}\right]^{4-}$ (which is the dominant form of 145 vanadate at $C_{\mathrm{v}} 10^{-2} \mathrm{M}$ and $\mathrm{pH} 8-10 ;^{12}$ the final $\mathrm{pH}$ dropped to 146 10.3), together with a small amount of a new product. The 147 controlled evaporation solution gave a tiny amount of 148 hexagonal plates of $\mathrm{Na}_{9} \mathrm{H}_{4}\left[\mathrm{VNb}_{12} \mathrm{O}_{40}\left\{\mathrm{NbO}\left(\mathrm{CO}_{3}\right)\right\}_{2}\right] \cdot 37 \mathrm{H}_{2} \mathrm{O} 149$ (1). The incorporation of carbonate was due to absorption of 150 $\mathrm{CO}_{2}$ from air by the strongly basic solution of hexaniobate. 151 Consequently, addition of $\mathrm{NaHCO}_{3}$ significantly improves the 152 yield of 1 (up to 13\%) and makes it possible to study its 153 chemistry.

The vanadatotetrakaidekaniobate $\left[\mathrm{VNb}_{14} \mathrm{O}_{42}\left(\mathrm{CO}_{3}\right)_{2}\right]^{13-}{ }_{155}$ anion present in $\mathbf{1}$ (Figure 1) has an $\alpha$-Keggin-type structure $156 \mathrm{fl}$

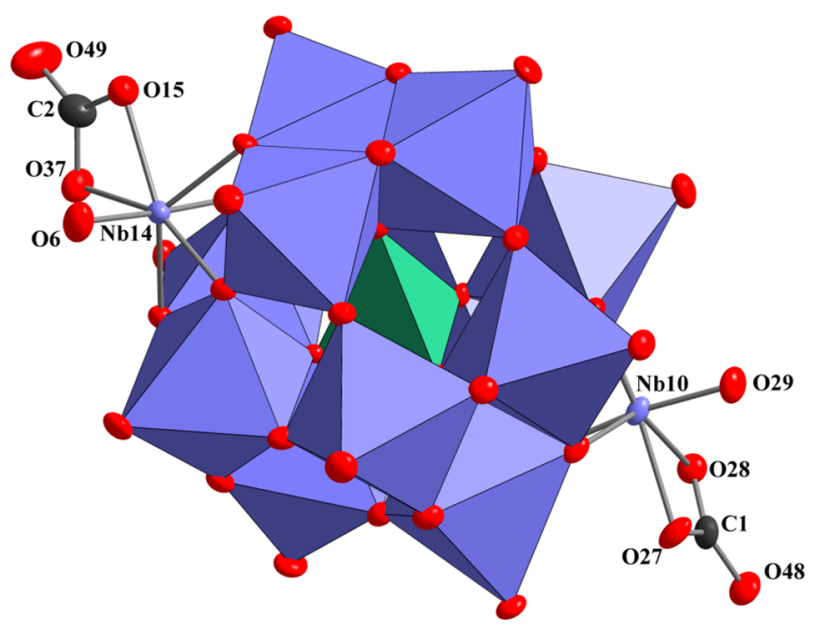

Figure 1. Structure of $\left[\mathrm{VNb}_{14} \mathrm{O}_{42}\left(\mathrm{CO}_{3}\right)_{2}\right]^{13-}$ (thermal ellipsoids drawn with $50 \%$ probability). Main bond distances: $d(\mathrm{O} 6-\mathrm{Nb} 14)=$ $1.772(7) \AA ; d(\mathrm{O} 15-\mathrm{Nb} 14)=2.181(7) \AA ; d(\mathrm{O} 37-\mathrm{Nb} 14)=2.149(7)$ $\AA ; d(\mathrm{O} 27-\mathrm{Nb} 10)=2.175(7) \AA ; d(\mathrm{O} 28-\mathrm{Nb} 10)=2.170(6) \AA ;$ $d(\mathrm{O} 29-\mathrm{Nb} 10)=1.774(7) \AA ; d(\mathrm{~V}-\mathrm{O})_{\mathrm{av}}=1.695(6) \AA$.

with two extra $\left\{\mathrm{NbO}\left(\mathrm{CO}_{3}\right)\right\}^{+}$caps, where the niobium atom 157 has coordination number 7 . BVS for oxygen atoms of $\mathrm{CO}_{3}{ }^{2-}{ }_{158}$ (Table S3) agrees with partial protonation of O49. This mode 159 of capping is typical for highly charged heterododecaniobates: 160 in $\mathrm{K}_{12}\left(\mathrm{Ti}_{2} \mathrm{O}_{2}\right)\left[\mathrm{SiNb}_{12} \mathrm{O}_{40}\right] \cdot 16 \mathrm{H}_{2} \mathrm{O}$, the Keggin anions $\left[\mathrm{SiNb}_{12}-161\right.$ $\left.\mathrm{O}_{40}\right]^{16-}$ are capped by additional $\{\mathrm{TiO}\}^{2+}$ groups which unite 162 them into infinite chains. ${ }^{13}$ In $\mathrm{Na}_{10}\left(\mathrm{Nb}_{2} \mathrm{O}_{2}\right)\left[\mathrm{TNb}_{12} \mathrm{O}_{40}\right] \cdot x \mathrm{H}_{2} \mathrm{O} \quad 163$ $(\mathrm{T}=\mathrm{Si}, \mathrm{Ge})$, there are additional $\{\mathrm{NbO}\}^{3+}$ caps with a similar 164 function. ${ }^{14}$ However, there are also uncapped dodecaniobates, 165 as is the case of $\mathrm{Na}_{16}\left[\mathrm{TNb}_{12} \mathrm{O}_{40}\right] \cdot 4 \mathrm{H}_{2} \mathrm{O}(\mathrm{T}=\mathrm{Si}, \mathrm{Ge}){ }^{15}$ Single 166 capped germano- and silicododecaniobates, namely, $\mathrm{Rb}_{13^{-}} 167$ $\left[\mathrm{GeNb}_{13} \mathrm{O}_{41}\right] \cdot 23 \mathrm{H}_{2} \mathrm{O}, \mathrm{Cs}_{10.6}\left[\mathrm{H}_{2.4} \mathrm{GeNb}_{13} \mathrm{O}_{41}\right] \cdot 27 \mathrm{H}_{2} \mathrm{O}$, and 168 $\mathrm{Cs}_{18} \mathrm{H}_{6}\left[(\mathrm{NbOH}) \mathrm{SiNb}_{12} \mathrm{O}_{40}\right]_{2} \cdot 38 \mathrm{H}_{2} \mathrm{O}$, were isolated. ${ }^{16}$ Small 169 


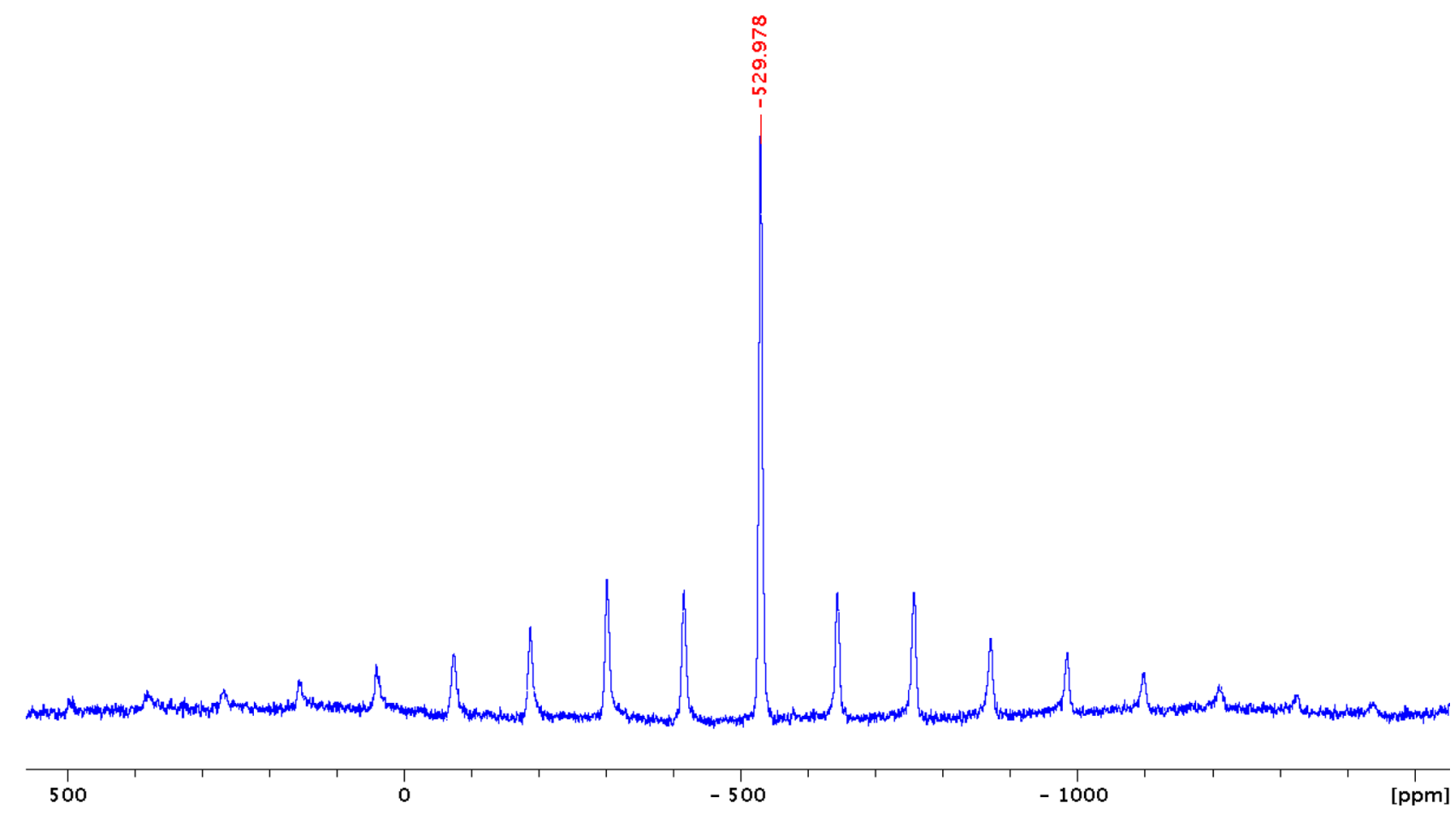

Figure 2. ${ }^{51} \mathrm{~V}$ MASS NMR spectrum of $\mathbf{1}$.

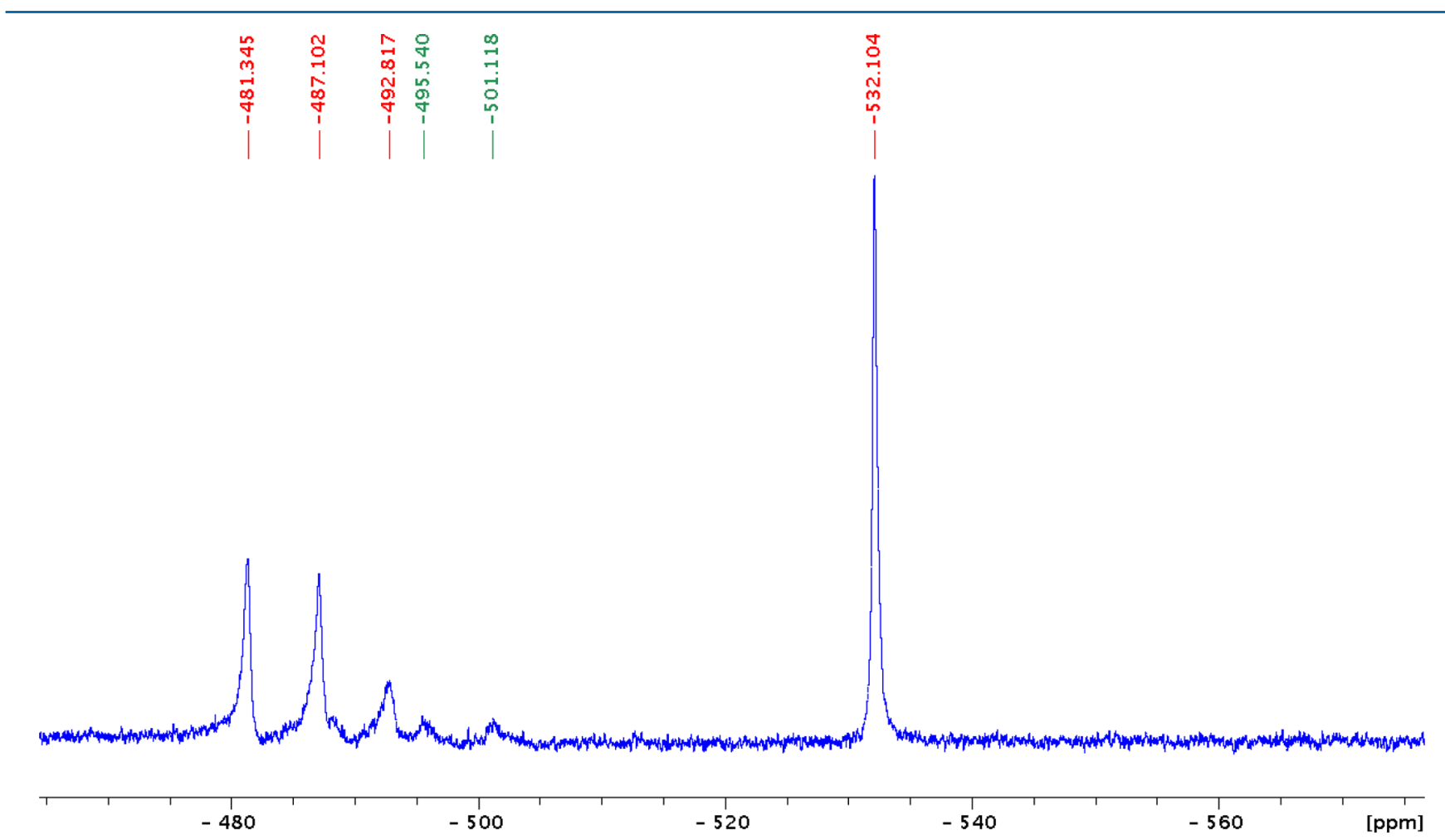

Figure 3. ${ }^{51} \mathrm{~V}$ NMR spectrum of the solution of $\mathbf{1}$ at natural $\mathrm{pH}$.

170 angle X-ray scattering (SAXS) studies on the solutions of $171 \mathrm{Rb}_{13}\left[\mathrm{GeNb}_{13} \mathrm{O}_{41}\right] \cdot 23 \mathrm{H}_{2} \mathrm{O}$ and $\mathrm{Cs}_{10.6}\left[\mathrm{H}_{2.4} \mathrm{GeNb}_{13} \mathrm{O}_{41}\right] \cdot 27 \mathrm{H}_{2} \mathrm{O}$ 172 revealed oligomerization of the monomers into the chain 173 structures through the dimerization of the $\{\mathrm{NbO}\}^{3+}$ caps. The 174 extent of the oligomerization is controlled by $\mathrm{pH}$, concen175 tration, and the counterion, and chains built of up to six Keggin 176 links with large were observed in the presence of large alkali 177 metal cations. In our case, the polymerization of the
$\left[\mathrm{VNb}_{12} \mathrm{O}_{40}\{\mathrm{NbO}\}_{2}\right]^{10-}$ bicapped Keggin anions is blocked by 178 coordination of $\mathrm{CO}_{3}{ }^{2-}$ to the coordinatively unsaturated 179 capping $\mathrm{Nb}$ atoms ( $\mathrm{CN}$ would be 5 without carbonate). The 180 main bond distances in $\left[\mathrm{VNb}_{14} \mathrm{O}_{42}\left(\mathrm{CO}_{3}\right)_{2}\right]^{13-}$ are listed in 181 Figure 1.

The lighter analogue of niobium-vanadium-also forms a 183 similar bicapped Keggin anion $\left[\mathrm{PV}_{14} \mathrm{O}_{42}\right]^{9-}$, but under strongly 184 acidic conditions. ${ }^{17}$ Due to the smaller ionic radius of $\mathrm{V}^{5+}$, it 185 


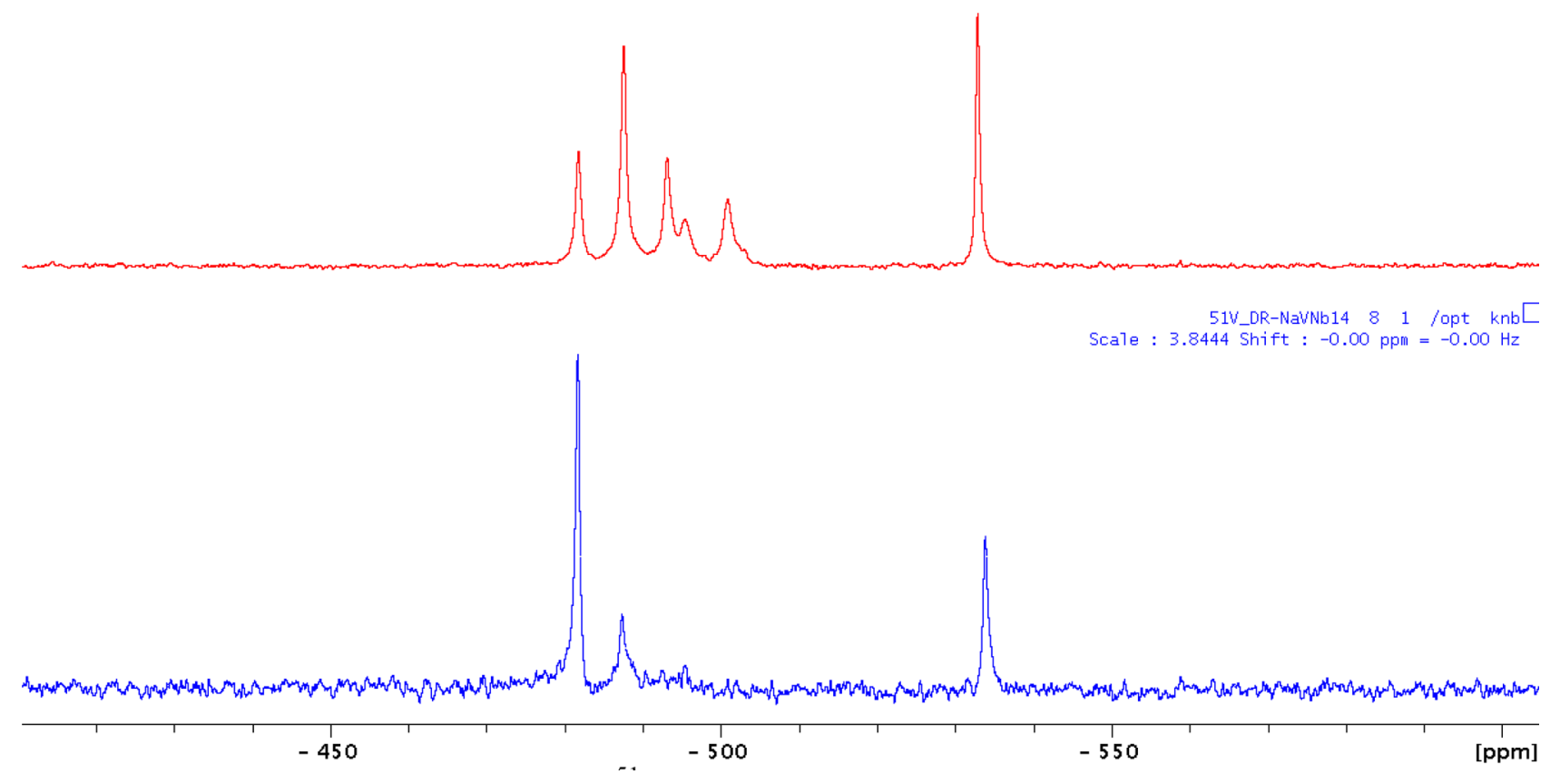

Figure 4. Concentration dependence of ${ }^{51} \mathrm{~V}$ NMR signals in 1. Upper spectrum recorded for $4.7 \mathrm{mM}$, lower for $0.8 \mathrm{mM}$ aqueous solutions.

186 shows no tendency to polymerize into the chains and 187 apparently exists only in the monomeric form. The $\{\mathrm{VO}\}^{n+}$ 188 groups can also cap highly charged reduced dodecamolybdate 189 Keggin anions, as in $\left[\mathrm{PMo}_{12} \mathrm{O}_{40}(\mathrm{VO})_{2}\right]^{n-18}$ or $\left[\mathrm{GeMo}_{12} \mathrm{O}_{40^{-}}\right.$ $\left.190(\mathrm{VO})_{2}\right]^{3-} \cdot{ }^{19}$ The $\left[\mathrm{PMo}_{12} \mathrm{O}_{40}(\mathrm{VO})_{2}\right]^{n-}$ has been assessed as an 191 important model for spin qubit because the redox-active core 192 unit of the Keggin phosphomolybdate is capped on the 193 opposed positions by two vanadyl ions $(2+)$, each containing a 194 localized spin of $1 / 2$. These spins can be coupled through the 195 electrons of the central core by electrical manipulation of the 196 molecular redox potential owing to the change of charge. ${ }^{20}$ The $197\{\mathrm{VO}\}^{3+}$ caps can be coordinated to Keggin-type dodecaniobates 198 in (TMA) ${ }_{9}\left[\mathrm{~V}_{3} \mathrm{Nb}_{12} \mathrm{O}_{42}\right] \cdot 18 \mathrm{H}_{2} \mathrm{O}^{21}$ and $\left[\mathrm{Cu}(\mathrm{en})_{2}\right]_{3.5}\left[\mathrm{Cu}(\mathrm{en})_{2}\right.$ $\left.199\left(\mathrm{H}_{2} \mathrm{O}\right)\right]\left\{\left[\mathrm{VNb}_{12} \mathrm{O}_{40}(\mathrm{VO})_{2}\right]\left[\mathrm{Cu}(\mathrm{en})_{2}\right]\right\} \cdot 17 \mathrm{H}_{2} \mathrm{O}{ }^{22}$ In this way, 200 they can even occupy up to six vertex positions, as in $201\left[\mathrm{Cu}(\mathrm{en})_{2}\right]_{4}\left[\mathrm{PNb}_{12} \mathrm{O}_{40}(\mathrm{VO})_{6}\right](\mathrm{OH})_{5} \cdot 8 \mathrm{H}_{2} \mathrm{O}$ and in $[\mathrm{Cu}-$ $\left.202(\mathrm{enMe})_{2}\right]_{4}\left[\mathrm{PNb}_{12} \mathrm{O}_{40}(\mathrm{VO})_{6}\right](\mathrm{OH})_{5} \cdot 6 \mathrm{H}_{2} \mathrm{O}$ (en = 1,2-ethylene203 diamine and enMe $=1,2$-diaminopropane) ${ }^{23}$ In our case, we 204 used a $\mathrm{Nb}: \mathrm{V}=6: 1$ atomic ratio and no vanadyl caps entered the 205 structure. Reactions with larger vanadium-to-niobium molar 206 ratios are under investigation.

207 Recently $\mathrm{Su}$ et al. reported preparations of $\left[\mathrm{Na}\left(\mathrm{H}_{2} \mathrm{en}\right)_{5}\right]$ $208\left[\mathrm{VNb}_{14} \mathrm{O}_{42}\left(\mathrm{NO}_{3}\right)_{2}\right] \cdot 12 \mathrm{H}_{2} \mathrm{O}$ and $\mathrm{K}_{7} \mathrm{Na}_{4}\left[\mathrm{VNb}_{14} \mathrm{O}_{42}\left(\mathrm{NO}_{3}\right)_{2}\right]$. $20931 \mathrm{H}_{2} \mathrm{O}$ by heating together $\mathrm{V}_{2} \mathrm{O}_{5}, \mathrm{NaOH}, \mathrm{K}_{7} \mathrm{H}\left[\mathrm{Nb}_{6} \mathrm{O}_{19}\right]$. $21013 \mathrm{H}_{2} \mathrm{O}, \mathrm{Co}\left(\mathrm{NO}_{3}\right)_{2} \cdot 6 \mathrm{H}_{2} \mathrm{O}$, and ethylenediamine. ${ }^{24} \mathrm{We}$ also 211 tried to switch from carbonate to nitrate, but no $\left[\mathrm{VNb}_{14} \mathrm{O}_{42^{-}}\right.$ $\left.212\left(\mathrm{NO}_{3}\right)_{2}\right]^{11-}$ was detected. It means that, under conditions as 213 used for preparation of $\mathbf{1}$, weakly coordinating nitrate cannot 214 stabilize the vanadododecaniobate structure.

Solid State and Solution Studies of 1. A crystalline 216 sample of 1 was studied with ${ }^{51} \mathrm{~V}$ and ${ }^{13} \mathrm{C}$ MASS NMR 217 techniques (Figure 2). In the ${ }^{51} \mathrm{~V}$ spectrum, at a rotation speed 218 of $15 \mathrm{kHz}$, a single line at $-530 \mathrm{ppm}$ from the $\left\{\mathrm{VO}_{4}\right\}^{3-}$ moiety 219 inside the bicapped Keggin was observed.

220 In ${ }^{13} \mathrm{C}$ MASS NMR, we found one unsymmetrical signal at $221166 \mathrm{ppm}(15 \mathrm{kHz})$ resulting from nonequal orientations of the $222 \mathrm{CO}_{3}{ }^{2-}$ ligands in the crystal structure (Figure S1). These data 223 confirm the individuality of the crystalline sample of $\mathbf{1}$.
However, dissolving $\mathbf{1}$ in water produces several species, 224 according to ${ }^{51} \mathrm{~V}$ NMR data (Figure 3). The main solution $225 \mathrm{f} 3$ signal at $-532 \mathrm{ppm}$ corresponds to $-530 \mathrm{ppm}$ assigned to the 226 signal from the bicapped Keggin anion in solid state. 227

In order to identify the other signals, we probed the solutions 228 of $\left[\mathrm{VNb}_{14} \mathrm{O}_{42}\left(\mathrm{CO}_{3}\right)_{2}\right]^{13-}$ with the ESI-MS technique (see 229 Figure S1 and Table S4). We observed two series of signals, 230 one from uncapped Keggin anions $\left(\left[\mathrm{VNb}_{12} \mathrm{O}_{40}+n \mathrm{Na}^{+}+231\right.\right.$ $\left.\left.m \mathrm{H}^{+}\right]^{2-}\right)$ and the other from bicapped Keggins $\left(\left[\mathrm{VNb}_{12} \mathrm{O}_{40^{-}} 232\right.\right.$ $\left.\left.\left\{\mathrm{NbO}\left(\mathrm{CH}_{3} \mathrm{O}\right)_{2}\right\}_{2}+x \mathrm{Na}^{+}+y \mathrm{H}^{+}\right]^{2-}\right)$, respectively. The 233 substitution of a carbonate ligand with two methoxo ligands 234 is due to the fact that the ESI-MS spectra were recorded 235 essentially in methanol with a small amount of water added. 236 Consequently, we have assigned the signals in the area between 237 -480 and $-510 \mathrm{ppm}$ to these species. Taking into account the 238 reported SAXS data on the solution behavior of $\left[\mathrm{GeNb}_{13^{-}} 239\right.$ $\left.\mathrm{O}_{41}\right]^{13-}$, we have also to admit that some of these signals might 240 correspond to oligomerization of the Keggin anions through 241 $\left\{\mathrm{Nb}_{2} \mathrm{O}_{2}\right\}$ bridges after the loss of carbonate. ${ }^{16} 242$

This oligomerization could not be detected under ESI-MS 243 conditions since the concentration of the sample was below 244 $10^{-5} \mathrm{M}$, which was much lower than that used for recording ${ }^{51} \mathrm{~V} 245$ NMR. In order to get a more consistent picture, we have 246 studied aqueous solutions of $\mathbf{1}$ with ${ }^{51} \mathrm{~V}$ NMR by varying the 247 concentration, and indeed found that several of these additional $248 \mathrm{f} 4$ signals decrease at lower concentrations (Figure 4). This is $249 \mathrm{f} 4$ consistent with the dissociation of oligomeric species. At the 250 same time, the relative intensity of the signal at $-482 \mathrm{ppm} 251$ significantly increases with dilution, while that of the parent 252 $\left[\mathrm{VNb}_{14} \mathrm{O}_{42}\left(\mathrm{CO}_{3}\right)_{2}\right]^{13-}$ anion at $-532 \mathrm{ppm}$ simultaneously 253 decreases. This can be explained by reversible dissociation of 254 the $\{\mathrm{NbO}\}^{3+}$ caps being favored in diluted solutions. 255

This experiment fixes the signal from the noncapped Keggin 256 form $\left[\mathrm{VNb}_{12} \mathrm{O}_{40}\right]^{15-}$ to $-482 \mathrm{ppm}$. Moreover, as a single- 257 capped link between $\left[\mathrm{VNb}_{12} \mathrm{O}_{40}\right]^{15-}$ and $\left[\mathrm{VNb}_{14} \mathrm{O}_{42}-258\right.$ $\left.\left(\mathrm{CO}_{3}\right)_{2}\right]^{13-}$, we have to admit the existence of a dimer 259 $\left\{\left[\mathrm{Nb}_{2} \mathrm{O}_{2}\right]\left[\mathrm{VNb}_{12} \mathrm{O}_{40}\right]_{2}\right\} .{ }^{24}$ If this is correct, the signal at -487260 ppm can be assigned to this species. 


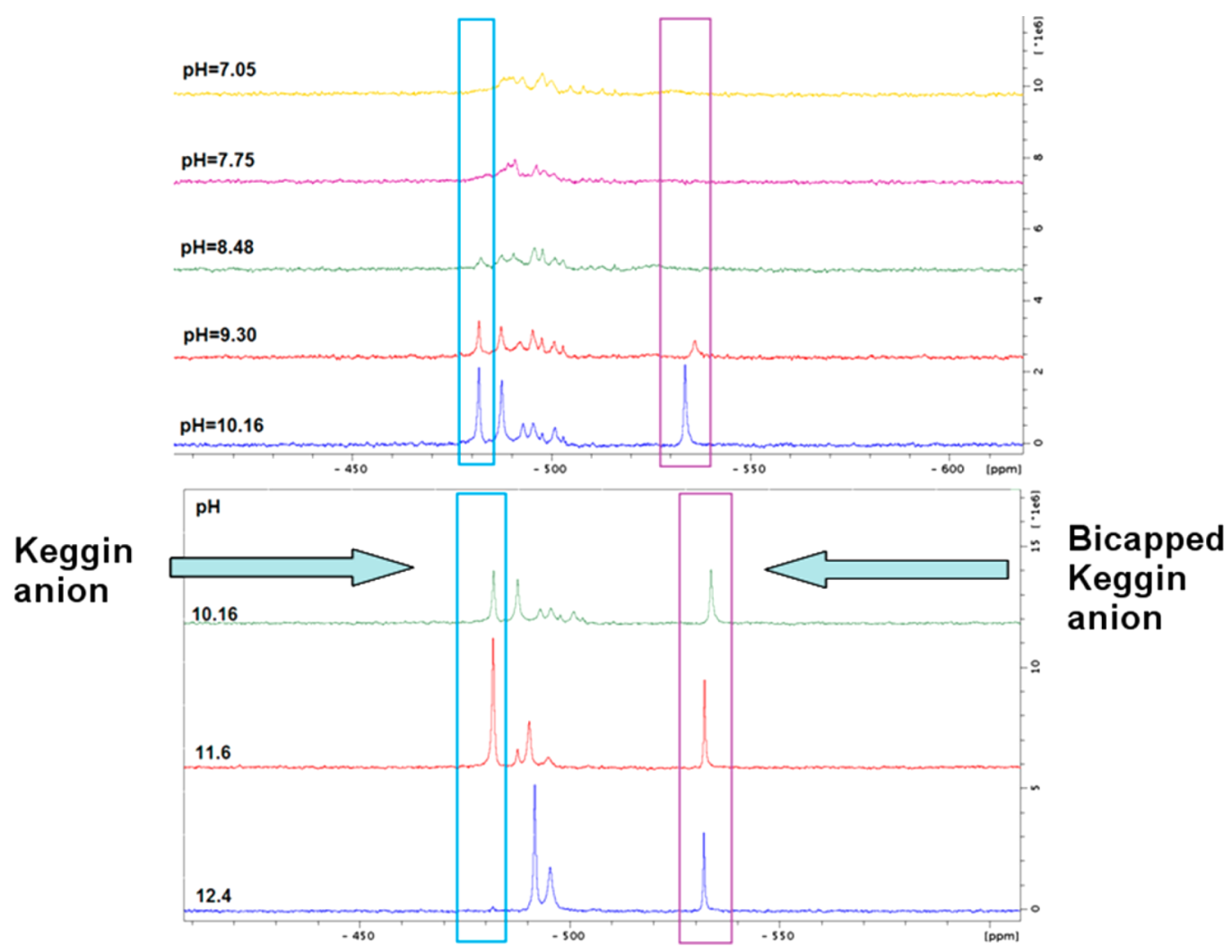

Figure 5. Dependence of ${ }^{51} \mathrm{~V}$ NMR signals of $\mathbf{1}$ from $\mathrm{pH}$ value.

262 We have run ${ }^{51} \mathrm{~V}$ NMR experiments at various $\mathrm{pHs}$ and 263 found that the relative stabilities of the capped and noncapped 264 Keggin ions are $\mathrm{pH}$-dependent (Figure 5).

265 From these data, we can estimate the $\mathrm{pH}$ stability windows 266 for $\left[\mathrm{VNb}_{12} \mathrm{O}_{40}\right]^{15-}$ and $\left[\mathrm{VNb}_{14} \mathrm{O}_{42}\left(\mathrm{CO}_{3}\right)_{2}\right]^{13-}$ as being $11.6 \div$ 2678.4 and $13 \div 9.2 \mathrm{pH}$ units, respectively. At $\mathrm{pH} \geq 12.4$, $268\left[\mathrm{VNb}_{12} \mathrm{O}_{40}\right]^{15-}$ is not detected, but the intensities of the -492 269 and $-496 \mathrm{ppm}$ peaks increase. This can be attributed to the 270 formation of the single-capped Keggin anion $\left[\mathrm{VNb}_{12} \mathrm{O}_{40}(\mathrm{NbO}-\right.$ $\left.\left.271\left(\mathrm{CO}_{3}\right)\right)\right]^{14-}$. Moreover, gradually reducing the $\mathrm{pH}$ value to 7 272 gives rise to an additional number of peaks clustering between $273-480$ and $-510 \mathrm{ppm}$, in accordance with the formation of $274\left(\mathrm{Nb}_{2} \mathrm{O}_{2}\right)$-bridged oligomers. Finally, at $\mathrm{pH} 7$, we observe only 275 these oligomeric forms. Remarkably, no free vanadate species 276 were detected in all of these experiments, indicating the 277 preservation of the Keggin structure within the investigated $\mathrm{pH}$ 278 window.

279 We could not find reference ${ }^{51} \mathrm{~V}$ NMR data for "trans280 vanadium" bicapped Keggin-type complexes $\left\{\mathrm{VNb}_{12} \mathrm{O}_{40^{-}}\right.$ $\left.281(\mathrm{VO})_{2}\right\},{ }^{22}$ nor are ${ }^{51} \mathrm{~V}$ MASS NMR data available for $282\left[\mathrm{Na}\left(\mathrm{H}_{2} \mathrm{en}\right)_{5}\right]\left[\mathrm{VNb}_{14} \mathrm{O}_{42}\left(\mathrm{NO}_{3}\right)_{2}\right] \cdot 12 \mathrm{H}_{2} \mathrm{O}$ and $\mathrm{K}_{7} \mathrm{Na}_{4}\left[\mathrm{VNb}_{14}\right.$ $\left.283 \mathrm{O}_{42}\left(\mathrm{NO}_{3}\right)_{2}\right] \cdot 31 \mathrm{H}_{2} \mathrm{O}$. ${ }^{24}$ However, ${ }^{51} \mathrm{~V}$ NMR spectra of (TMA) ${ }_{9}$ $284\left[\mathrm{~V}_{3} \mathrm{Nb}_{12} \mathrm{O}_{42}\right] \cdot 18 \mathrm{H}_{2} \mathrm{O}$ exhibited a sharp peak at $-520.0 \mathrm{ppm}$ and 285 a broad peak at $-528.1 \mathrm{ppm}$ with an approximate integrated 286 intensity ratio of $1: 2$, corresponding to a central $\mathrm{VO}_{4}$ and two 287 capping $\{\mathrm{VO}\}$ units in the cluster. ${ }^{21}$ Given the quadrupolar 288 nature of ${ }^{51} \mathrm{~V}$, a reasonable hypothesis would be to assign the 289 sharp signal to the symmetric $\mathrm{VO}_{4}$, and the broader peak at $290-528.1 \mathrm{ppm}$ to the less-symmetric capping $\mathrm{VO}_{5}$ sites. This 291 assignment agrees well with the ${ }^{51} \mathrm{~V}$ NMR studies of the 292 isostructural bicapped Keggin isopolyoxovanadate, $\left[\mathrm{VV}_{12} \mathrm{O}_{40^{-}}\right.$ $\left.293(\mathrm{VO})_{2}\right]^{9-}$, for which the signal from the central $\mathrm{VO}_{4}$ was 294 observed at $-507 \mathrm{ppm}$, and $\mathrm{VO}_{5}$ appeared at $-531 \mathrm{ppm} .^{25}$
Furthermore, for $\left[\mathrm{PV}_{12} \mathrm{O}_{40}(\mathrm{VO})_{2}\right]^{9-}$, the -523 ppm peak was 295 assigned to the $\mathrm{VO}_{5}$ caps, and the -575 ppm peak to the $\mathrm{VO}_{6} 296$ addenda. ${ }^{17}$

297

Isolation and Structure of 2. The chemistry of 298 polyoxoniobates and tantalates is strongly influenced by the 299 counterions. Aggregation of Lindqvist-type hexametalates with 300 cations both in solid state and in solution is well documented. ${ }^{\text {la }} 301$ Applying these considerations to higher-nuclearity PONb, we 302 have compared the products formed by heating hexaniobate 303 with vanadate: (i) in the presence of sodium solely and (ii) in 304 the presence of potassium and sodium. The pure $\mathrm{Na}^{+}$salts 305 yielded $\mathbf{1}$, while, in the presence of $\mathrm{K}^{+}$, after carefully monitored 306 evaporation of the filtrate from the reaction mixture, we 307 obtained crystals containing $\left[\mathrm{K} @ \mathrm{~V}_{x} \mathrm{Nb}_{24} \mathrm{O}_{76}\right]^{n-}$ (2) displaying a 308 hitherto unprecedented anion structure (Figure 6).

The anion is built of three edge-sharing $\left\{\mathrm{NbO}_{6}\right\}$ octahedra 310 having common vertices with three fused $\left\{\left(\mathrm{NbO}_{2}\right)\left(\mathrm{NbO}_{6}\right)_{5}\right\} 311$ pentagonal units, which, in turn, are additionally bridged with 312 three trans- $\left\{\mathrm{NbO}_{2}\right\}$ fragments, all forming the polyoxoniobate 313 backbone. Alternatively, the structure can be regarded as a 314 hybrid of a trilacunary $\left\{\mathrm{VNb}_{9}\right\}$ Keggin anion and a polyniobate 315 based on corner-shared pentagonal $\left\{\mathrm{NbNb}_{5}\right\}$ units, as found, 316 e.g., in the hexatriakontamolybdate $\left[\mathrm{Mo}_{36} \mathrm{O}_{112}\left(\mathrm{H}_{2} \mathrm{O}\right)_{16}\right]^{8-7} \cdot 317$ This particular combination is apparently without precedents in 318 the chemistry of polyoxomolybdates. There are five cavities 319 inside the anion: four pseudotetrahedral T-cavities (with four 320 short (1.829-2.088 $\AA$ ) and two long (2.395-2.434 $\AA$ ) V-O 321 distances) inside, and a large crown-ether like lacuna at the 322 bottom part. The T-cavities are occupied with vanadium with 323 either full or $3 / 4$ occupancy, and the large lacuna accommodates 324 a single $\mathrm{K}^{+}$cation (Figure S2). These four T-cavities form a 325 supertetrahedral cavity with the topology of the $\mathrm{P}_{4} \mathrm{O}_{10}$ cage. 326 


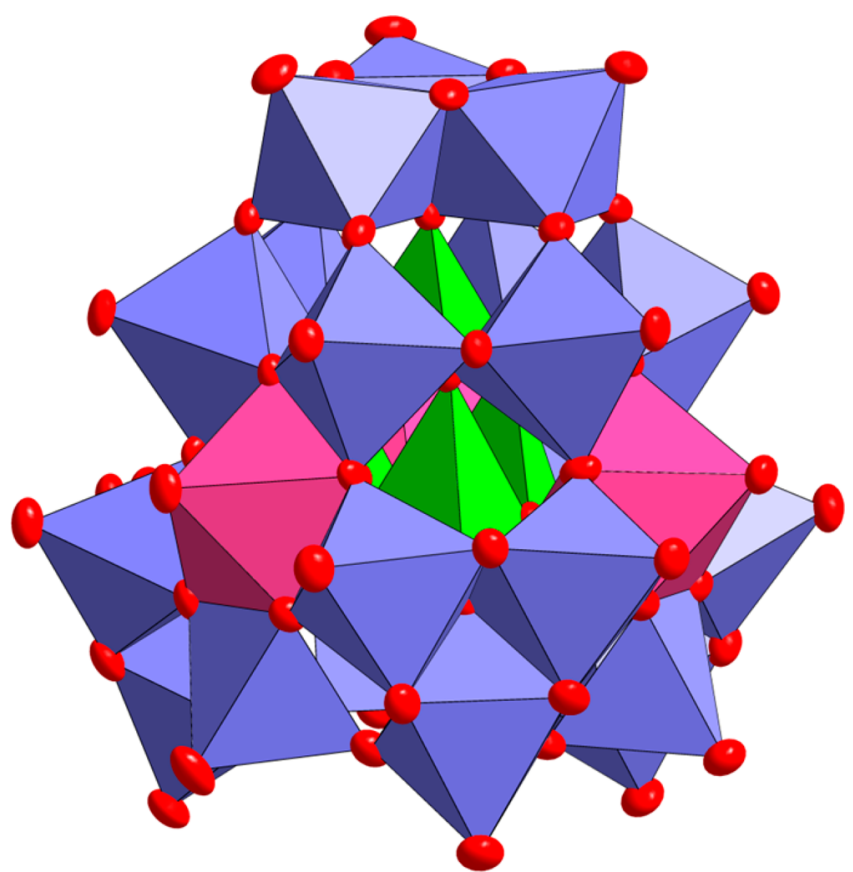

Figure 6. View of $\left[\mathrm{V}_{x} \mathrm{Nb}_{24} \mathrm{O}_{76}\right]^{n-}$ (combined ellipsoid (50\% probability) and polyhedral model). Vanadium polyhedra are shown in green, niobium polyhedra with $\mathrm{CN} 7$ in pink.

327 Due to the presence of two closely related types of anions of 328 the same geometry in 2 , which contains cocrystallized $329\left[\mathrm{~V}_{x} \mathrm{Nb}_{24} \mathrm{O}_{76}\right]^{n-}$ (with $x=4, n=12(\mathbf{2 a})$ and $x=3, n=17$ $330(\mathbf{2 b})$ ), one of the $\mathrm{T}$-cavities is free (or, more probably, is 331 occupied by a proton). The heptaeicosaniobate $\mathrm{K}_{13} \mathrm{Na}_{3}\left[\mathrm{HNb}_{27^{-}}\right.$ $\left.332 \mathrm{O}_{76}\right] \cdot 25 \mathrm{H}_{2} \mathrm{O}$ reported by Cronin et al. has a related structure, 333 with one $\mathrm{T}$-cavity occupied with a proton. ${ }^{5}$ In its crystal 334 structure, however, the $\mathrm{PONb}$ anions are severely disordered, 335 which has made it difficult to refine the structure and 336 composition of this POM. From the obvious relationship 337 between the structures of $\left[\mathrm{V}_{4} \mathrm{Nb}_{24} \mathrm{O}_{76}\right]^{12-}$ and $\left[\mathrm{HNb}_{27} \mathrm{O}_{76}\right]^{16-}$, 338 we suggest that both anions should have the same set of $\mathrm{T}$ 339 cavities, which could be occupied with vanadium (in 2) or 340 niobium (in $\left[\mathrm{HNb}_{27} \mathrm{O}_{76}\right]^{16-}$ ). The only problem is that, for $341 \mathrm{Nb}^{5+}$, this would be a very rare case of tetrahedral coordination 342 with four $\mathrm{O}^{2-}$ ligands. We have compared the coordination of $343 \mathrm{~V}^{5+}$ and supposed $\mathrm{Nb}^{5+}$ inside the $\mathrm{T}$-cavities (Figure 7). In both 344 cases, there are four short and two long $\mathrm{M}-\mathrm{O}$ distances, and in the case of $\mathrm{Nb}$, the coordination can be described as a highly 345 distorted tetrahedron with two additionally coordinated oxides. 346 Such an arrangement was found only in the rare-earth 347 orthoniobates $\mathrm{LnNbO}_{4}$ (Fergusonite-type mineral), which can 348 also be synthesized at the temperature range between 500 and 349 $1100{ }^{\circ} \mathrm{C} .{ }^{26}$ Accordingly to the neutron diffraction experiments, 350 the $\mathrm{Nb}-\mathrm{O}$ distances in such a tetrahedron are $1.834 \AA^{27} .^{27}$ Recently, Kolis et al. also reported about the synthesis of rare 352 earth orthoniobates $\mathrm{RENbO}_{4}(\mathrm{RE}=\mathrm{Y}, \mathrm{La}-\mathrm{Lu}){ }^{28}$

353

These compounds were grown as large single crystals in 30354 $\mathrm{M} \mathrm{KOH}$ at $700{ }^{\circ} \mathrm{C}$ and $2 \mathrm{kbar}$. Niobium occupies a $4 \mathrm{e}$ Wyckoff 355 position having 2 -fold symmetry and forms shorter bonds to 356 four oxygen atoms with a narrow spread of distances (average 357 $\mathrm{Nb}-\mathrm{O}$ distances of $1.846(5)$ and $1.927(5) \AA$ across the 358 $\mathrm{RENbO}_{4}$ family) and much longer bonds to two other oxygen 359 atoms (average $\mathrm{Nb}-\mathrm{O}$ distance of $2.455(5) \AA$ ) to form the 360 distorted $\mathrm{NbO}_{6}$ unit. It seems not very likely that already at 200361 ${ }^{\circ} \mathrm{C}$ niobium would spontaneously enter such energetically 362 disfavored positions. A kind of a structural artifact arising from 363 the disorder is not to be discarded, and perhaps the $\mathrm{Nb} 364$ occupancies of the T-cavities in $\left[\mathrm{HNb}_{27} \mathrm{O}_{76}\right]^{16-}$ should, in fact, 365 be less than 1 , if not zero. Unfortunately, we also have 366 encountered severe problems with crystal diffraction in $\mathbf{2}$ due to 367 the formation of stacks of poorly diffracting very thin plates. 368

It is also interesting that, in the presence of roughly 369 equimolar amounts of $\mathrm{K}^{+}(2.17 \mathrm{mmol})$ and $\mathrm{Na}^{+}(1.90 \mathrm{mmol}) 370$ used in the preparation of $\mathbf{2}$, it is exclusively potassium that 371 enters the lacuna. If one compares the cation-accommodating 372 lacuna in $\mathbf{2}$ with what is found in other polyniobates, one can 373 cite $\left[\mathrm{K} @ \mathrm{Nb}_{24} \mathrm{O}_{72} \mathrm{H}_{9}\right]^{14-}$, which has a very similar crown-ether 374 like cavity flanked by six $\left\{\mathrm{NbO}_{6}\right\}$ fragments. Moreover, such a 375 cyclic structure occurs in a pyrochlore mineral $(\mathrm{Na}, \mathrm{Ca})_{2}-376$ $\mathrm{Nb}_{2} \mathrm{O}_{6}(\mathrm{OH}, \mathrm{F}){ }^{29}$ Hence, we can suggest that this cyclic 377 arrangement $\left\{\mathrm{K} @\left(\mathrm{NbO}_{6}\right)_{6}\right\}$ is energetically preferred at higher 378 temperatures and can be generated and used as a building block 379 for construction of various polyniobates.

380

Looking across the periodic table for structural analogues of 381 2, we have found structures of $\left[\mathrm{H}_{2} \mathrm{Ti}_{28} \mathrm{O}_{38}(\mathrm{OEt})_{40} \mathrm{LnCl}\right](\mathrm{Ln}=382$ $\mathrm{La}, \mathrm{Ce})$ with a closely related metal core, which also contain 383 three pentagonal $\left\{(\mathrm{Ti}) \mathrm{Ti}_{5}\right\}$ building blocks, and has a large 384 cavity flanked with six $\left\{\mathrm{TiO}_{6}\right\}$ octahedra, occupied with a $\mathrm{Ln}^{3+} 385$ cation. ${ }^{30}$ It is yet another example of the diagonal relationship 386 between niobium and titanium.

387

Solid State and Solution Studies of 2. The solubility of $\mathbf{2} 388$ in water is practically the same as of $\mathrm{KVO}_{3}$, which makes 389
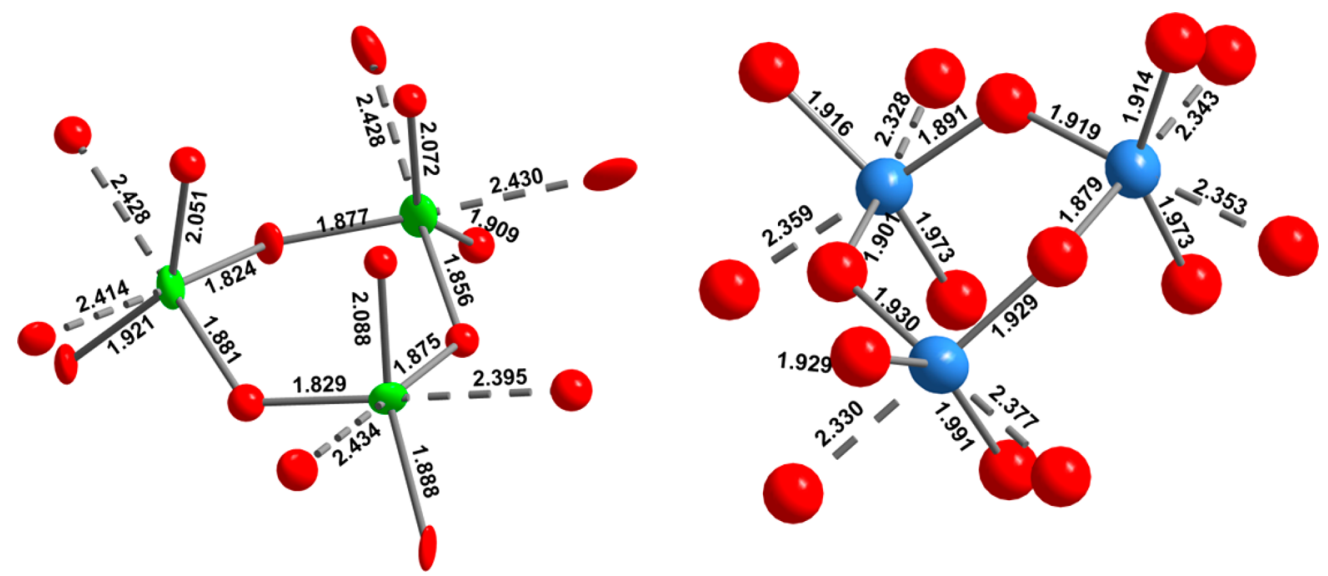

Figure 7. Comparison of the T-cavities geometry in 2 (left) and in CSD 420848 (right). 


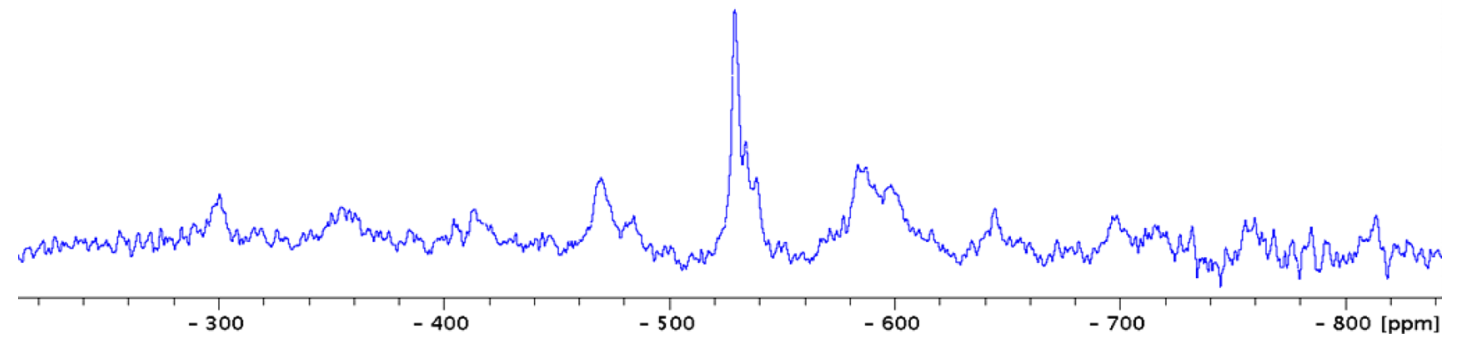

Figure 8. ${ }^{51} \mathrm{~V}$ MASS NMR for 2 . Intensity of satellites is low due to low content of $\mathbf{2}$ (mixed with $\mathrm{SiO}_{2}$ ).

390 fractional crystallization of this complex very complicated, and 391 the purity of the bulk product does not allow exact 392 determination of the analytical composition. Moreover, the 393 simultaneous presence of two anions in the single crystal phase 394 turns fitting analytical data unequivocally into a very difficult 395 task. We studied solutions of several crystals of 2, picked up 396 manually, with ESI-MS, and always found two overlapping 397 series of anions: $\left[\mathrm{CH}_{3} \mathrm{OH}+\mathrm{V}_{4} \mathrm{Nb}_{24} \mathrm{O}_{76}+x \mathrm{~K}+y \mathrm{H}\right]^{3-},\left[\mathrm{H}_{2} \mathrm{O}+\right.$ $\left.398 \mathrm{~V}_{4} \mathrm{Nb}_{24} \mathrm{O}_{76}+x \mathrm{Na}+y \mathrm{H}\right]^{3-},\left[\mathrm{H}_{2} \mathrm{O}+\mathrm{V}_{3} \mathrm{Nb}_{24} \mathrm{O}_{76}+x \mathrm{~K}+y \mathrm{H}\right]^{3-}$, $399\left[\mathrm{CH}_{3} \mathrm{OH}+\mathrm{V}_{3} \mathrm{Nb}_{24} \mathrm{O}_{76}+x \mathrm{~K}+y \mathrm{H}\right]^{3-},\left[\mathrm{H}_{2} \mathrm{O}+\mathrm{V}_{3} \mathrm{Nb}_{24} \mathrm{O}_{76}+\right.$ $400 x \mathrm{Na}+y \mathrm{H}]^{3-}$ (see Table S5, Figure S4). These data confirm the 401 individuality of $\left[\mathrm{V}_{4} \mathrm{Nb}_{24} \mathrm{O}_{76}\right]^{12-}$ and $\left[\mathrm{V}_{3} \mathrm{Nb}_{24} \mathrm{O}_{76}\right]^{17-}$ present in 4022.

403 In the ${ }^{51} \mathrm{~V}$ MASS NMR, there is a set of signals centered at $404-530 \mathrm{ppm}$ (Figure 8). In solution, they merge into a single line 405 at $-532 \mathrm{ppm}$ ( $150 \mathrm{~Hz}$ width), due to the quadrupolar nature of 406 the ${ }^{51} \mathrm{~V}$ nucleus.

407 In the Raman spectra of $\mathbf{1}$ and 2 , there are sets of $\mathrm{Nb}-\mathrm{O}$ and $408 \mathrm{~V}-\mathrm{O}$ vibrations (Figure S5): 1065 (m), 913(vs), 856(s), 368 $409(\mathrm{~m}), 250(\mathrm{~m}), 215(\mathrm{~m})$ for 1 and $1065(\mathrm{~m}), 935(\mathrm{vs}), 919(\mathrm{~s})$, $410907(\mathrm{~s}), 867(\mathrm{~m}), 647(\mathrm{~m}), 498(\mathrm{~m}), 360(\mathrm{~m}), 329(\mathrm{~m}), 244$ $411(\mathrm{~m}), 211(\mathrm{~m})$ for 2 . The bands at $1065 \mathrm{~cm}^{-1}$ can be assigned to 412 the tetrahedral $\mathrm{VO}_{4}$ units. The strong bands at 913 (1) and 935 413 (2) $\mathrm{cm}^{-1}$ should correspond to terminal $\mathrm{Nb}=\mathrm{O}$ groups. The $414 \mathrm{Nb}-\mathrm{O}-\mathrm{Nb}$ bridges appear below $900 \mathrm{~cm}^{-1}$, as can be expected 415 from the comparison with the Raman spectra of $\mathrm{ANbO}_{3}$ (the 416 highest frequency $\mathrm{Nb}-\mathrm{O}$ bands at $876 \mathrm{~cm}^{-1}$ (for $\mathrm{Li}^{+}$), 800 $417 \mathrm{~cm}^{-1}$ (for $\mathrm{Na}^{+}$), $832 \mathrm{~cm}^{-1}$ (for $\left.\mathrm{K}^{+}\right)$). ${ }^{31}$ In $\mathrm{CaNb}_{2} \mathrm{O}_{6}$, the $\mathrm{Nb}-\mathrm{O}$ 418 band appears at $904 \mathrm{~cm}^{-1}$, and in $\mathrm{AlNbO}_{4}$ at $932 \mathrm{~cm}^{-1}$. ${ }^{31}$

\section{CONCLUSION}

420 This research demonstrates rich synthetic possibilities of 421 thermal rearrangements of hexaniobate, which, depending on 422 the cationic composition of the reaction mixture, can follow 423 different pathways. In the case of sodium, we isolated $424 \mathrm{Na}_{9} \mathrm{H}_{4}\left[\mathrm{VNb}_{12} \mathrm{O}_{40}\left\{\mathrm{NbO}\left(\mathrm{CO}_{3}\right)\right\}_{2}\right] \cdot 34 \mathrm{H}_{2} \mathrm{O}$ consisting of a bicap425 ped $\alpha$-Keggin-type $\mathrm{V}$-centered polyoxoniobate. In water, it 426 equilibrates with vanadododecaniobate and polymeric forms by 427 a process involving the loss of coordinated carbonate, one or 428 two $\{\mathrm{NbO}\}^{3+}$ caps, and oligomerization by their transformation 429 into $\left\{\mathrm{Nb}_{2} \mathrm{O}_{2}\right\}^{6+}$ linkers. In the presence of potassium, we 430 isolated a solid phase containing two unique $\left[\mathrm{V}_{4} \mathrm{Nb}_{24} \mathrm{O}_{76}\right]^{12-}$ 431 and $\left[\mathrm{V}_{3} \mathrm{Nb}_{24} \mathrm{O}_{76}\right]^{17-}$ anions with the topology of a trigonal 432 pyramid. These PONb have a hybrid metal-oxo backbone 433 consisting of a fragment of the Keggin structure fused with 434 pentagonal $\left\{\mathrm{NbNb}_{5}\right\}$ building blocks, arranged around a central 435 tetrahedral cavity. The cavity is occupied by three or four $\mathrm{V}^{5+}$ 436 ions. In this way, $\left[\mathrm{V}_{4} \mathrm{Nb}_{24} \mathrm{O}_{76}\right]^{12-}$ can be regarded as a 437 polyniobate assembled around $\mathrm{V}_{4} \mathrm{O}_{10}$ as template- $-\mathrm{a}$ molecular 438 analogue of $\mathrm{P}_{4} \mathrm{O}_{10}$, unknown in the free state, but stabilized when trapped into PONb. $\left[\mathrm{V}_{3} \mathrm{Nb}_{24} \mathrm{O}_{76}\right]^{17-}$ can be similarly 439 regarded as incorporating cyclic trivanadate $\left[\mathrm{V}_{3} \mathrm{O}_{9}\right]^{3-}$, which 440 has negligible contribution to the equilibria in the solutions of 441 free vanadates. In this work, we have also demonstrated 442 remarkable tendency of a cyclic $\left\{\mathrm{K} @\left(\mathrm{NbO}_{6}\right)_{6}\right\}$ building block 443 to assemble at higher temperatures.

\section{ASSOCIATED CONTENT \\ ASSOCIATED CONTENT}

444

445

S Supporting Information

446

The Supporting Information is available free of charge on the 447 ACS Publications website at DOI: 10.1021/acs.inorg- 448 chem.6b02108.

449

Additional structural information, ESI(-)-MS data, and 450 Raman spectra (PDF)

Crystallographic data for $\mathbf{1}$ (CIF)

Crystallographic data for $\mathbf{2}$ (CIF)

451

452

453

AUTHOR INFORMATION

454

Corresponding Author

*E-mail: abramov@niic.nsc.ru.

ORCID ${ }^{\circ}$

Pavel A. Abramov: 0000-0003-4479-5100

455

Funding

The work was supported by the Russian Science Foundation 460 (RScF 14-13-00645).

Notes

The authors declare no competing financial interest.

\section{REFERENCES}

(1) (a) Nyman, M. Polyoxoniobate chemistry in the 21st century. 465 Dalton Trans. 2011, 40, 8049-8058. (b) Kinnan, M. K.; Creasy, W. R.; 466 Fullmer, L. B.; Schreuder-Gibson, H. L.; Nyman, M. Nerve Agent 467 Degradation with Polyoxoniobates. Eur. J. Inorg. Chem. 2014, 2014, 468 2361-2367. (c) Abramov, P. A.; Vicent, C.; Kompankov, N. B.; 469 Gushchin, A. L.; Sokolov, M. N. Platinum polyoxoniobates. Chem. 470 Commun. 2015, 51, 4021-4023. (d) Abramov, P. A.; Sokolov, M. N.; 471 Virovets, A. V.; Floquet, S.; Haouas, M.; Taulelle, F.; Cadot, E.; Vicent, 472 C.; Fedin, V. P. Grafting $\left\{\mathrm{Cp}^{*} \mathrm{Rh}\right\}^{2+}$ on the surface of $\mathrm{Nb}$ and $\mathrm{Ta} 473$ Lindqvist-type POM. Dalton Trans. 2015, 44, 2234-2239. (e) Son, J.- 474 H.; Wang, J.; Casey, W. H. Structure, stability and photocatalytic $\mathrm{H}_{2} 475$ production by $\mathrm{Cr}-, \mathrm{Mn}-, \mathrm{Fe}-$, $\mathrm{Co}-$, , and Ni-substituted decaniobate 476 clusters. Dalton Trans. 2014, 43, 17928-17933.

(2) (a) Huang, P.; Qin, C.; Su, Z.-M.; Xing, Y.; Wang, X.-L.; Shao, 478 K.-Z.; Lan, Y.-Q.; Wang, E.-B. Self-Assembly and Photocatalytic 479 Properties of Polyoxoniobates: $\left\{\mathrm{Nb}_{24} \mathrm{O}_{72}\right\},\left\{\mathrm{Nb}_{32} \mathrm{O}_{96}\right\}$, and 480 $\left\{\mathrm{K}_{12} \mathrm{Nb}_{96} \mathrm{O}_{288}\right\}$ Clusters. J. Am. Chem. Soc. 2012, 134, 14004-14010. 481 (b) Wang, Z.-L.; Tan, H.-Q.; Chen, W.-L.; Li, Y.-G.; Wang, E.-B. A 482 copper(II)-ethylenediamine modified polyoxoniobate with photo- 483 catalytic H2 evolution activity under visible light irradiation. Dalton 484 Trans. 2012, 41, 9882-9884. 
486 (3) (a) Fielden, J.; Sumliner, J. M.; Han, N.; Geletii, Y. V.; Xiang, X.; 487 Musaev, D. G.; Lian, T.; Hill, C. L. Water splitting with 488 polyoxometalate-treated photoanodes: enhancing performance 489 through sensitizer design. Chem. Sci. 2015, 6, 5531-5543. (b) Liu, 490 Y. P.; Zhao, S. F.; Guo, S. X.; Bond, A. M.; Zhang, J.; Zhu, G.; Geletii, 491 Y. V.; Hill, C. L. Electrooxidation of Ethanol and Methanol Using the 492 Molecular Catalyst $\left[\left\{\mathrm{Ru}_{4} \mathrm{O}_{4}(\mathrm{OH})_{2}\left(\mathrm{H}_{2} \mathrm{O}\right)_{4}\right\}\left(\gamma-\mathrm{SiW}_{10} \mathrm{O}_{36}\right)_{2}\right]^{10-}$. J. Am. 493 Chem. Soc. 2016, 138, 2617-2628.

494 (4) Niu, L.; Ma, P.; Niu, H.; Li, J.; Zhao, J.; Song, Y.; Wang, J. Giant 495 Polyniobate Clusters Based on $\left[\mathrm{Nb}_{7} \mathrm{O}_{22}\right]^{9-}$ Units Derived from a $496 \mathrm{Nb}_{6} \mathrm{O}_{19}$ Precursor. Chem. - Eur. J. 2007, 13, 8739-8748.

497 (5) Tsunashima, R.; Long, D.-L.; Miras, H. N.; Gabb, D.; Pradeep, C. 498 P.; Cronin, L. The Construction of High-Nuclearity Isopolyoxonio499 bates with Pentagonal Building Blocks: $\left[\mathrm{HNb}_{27} \mathrm{O}_{76}\right]^{16-}$ and $500\left[\mathrm{H}_{10} \mathrm{Nb}_{31} \mathrm{O}_{93}\left(\mathrm{CO}_{3}\right)\right]^{23-}$. Angew. Chem., Int. Ed. 2010, 49, 113-116.

501 (6) (a) Ikeya, T.; Senna, M. J. Change in the structure of niobium 502 pentoxide due to mechanical and thermal treatments. J. Non-Cryst. 503 Solids 1988, 105, 243-250. (b) Kato, K.; Tamura, S. Die

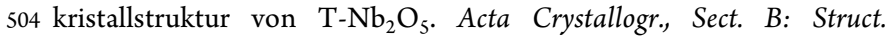
505 Crystallogr. Cryst. Chem. 1975, B31, 673-677.

506 (7) (a) Müller, A.; Das, S. K.; Fedin, V. P.; Krickemeyer, E.; 507 Beugholt, C.; Bögge, H.; Schmidtmann, M.; Hauptfleisch, B. Rapid 508 and Simple Isolation of the Crystalline Molybdenum-Blue Com509 pounds with Discrete and Linked Nanosized Ring-Shaped Anions:

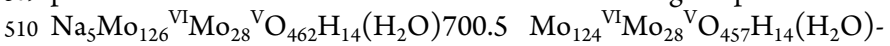
$511680.5 \mathrm{C} \mathrm{A} .400 \mathrm{H}_{2} \mathrm{O}$ a $\mathrm{n} \mathrm{d}$ $512 \mathrm{Na}_{22} \mathrm{Mo}_{118}{ }^{\mathrm{VI}} \mathrm{Mo}_{28}{ }^{\mathrm{V}} \mathrm{O}_{442} \mathrm{H}_{14}\left(\mathrm{H}_{2} \mathrm{O}\right)_{58} \mathrm{CA} .250 \mathrm{H}_{2} \mathrm{O}$. Z. Anorg. Allg. Chem. 513 1999, 625, 1187-1192. (b) Müller, A.; Krickemeyer, E.; Bögge, H.; 514 Schmidtmann, M.; Peters, F. Organizational Forms of Matter: An 515 Inorganic Super Fullerene and Keplerate Based on Molybdenum 516 Oxide. Angew. Chem., Int. Ed. 1998, 37, 3359-3363.

517 (8) Flynn, C. M.; Stucky, G. D. Sodium 6-niobo(ethylenediamine)518 cobaltate(III) and its chromate(III) analog. Inorg. Chem. 1969, 8, 519 178-180.

520 (9) Sheldrick, G. M. Crystal structure refinement with SHELXL. Acta 521 Crystallogr., Sect. C: Struct. Chem. 2015, C71, 3-8.

522 (10) Hübschle, C. B.; Sheldrick, G. M.; Dittrich, B. ShelXle: a Qt 523 graphical user interface for SHELXL. J. Appl. Crystallogr. 2011, 44, $5241281-1284$.

525 (11) APEX2 (Version 1.08), SAINT (Version 7.03), and SADABS 526 (Version 2.11), Bruker Advanced X-ray Solutions; Bruker AXS Inc.: 527 Madison, WI, 2004.

528 (12) Pope, M. T. Heteropoly and Isopolyoxometalates; Springer-Verlag: 529 Berlin, 1983.

530 (13) Nyman, M.; Bonhomme, F.; Alam, T. M.; Rodriguez, M. A.; 531 Cherry, B. R.; Krumhansl, J. L.; Nenoff, T. M.; Sattler, A. M. A General 532 Synthetic Procedure for Heteropolyniobates. Science 2002, 297, 996533998.

534 (14) Nyman, M.; Bonhomme, F.; Alam, T. M.; Parise, J. B.; Vaughan, 535 G. M. B. $\left[\mathrm{SiNb}_{12} \mathrm{O}_{40}\right]^{16-}$ and $\left[\mathrm{GeNb}_{12} \mathrm{O}_{40}\right]^{16-}$ : Highly Charged Keggin 536 Ions with Sticky Surfaces. Angew. Chem., Int. Ed. 2004, 43, 2787-2792. 537 (15) Bonhomme, F.; Larentzos, J. P.; Alam, T. M.; Maginn, E. J.; 538 Nyman, M. Synthesis, Structural Characterization, and Molecular 539 Modeling of Dodecaniobate Keggin Chain Materials. Inorg. Chem. $5402005,44,1774-1785$.

541 (16) Hou, Y.; Zakharov, L. N.; Nyman, M. Observing assembly of 542 complex inorganic materials from polyoxometalate building blocks. $J$. 543 Am. Chem. Soc. 2013, 135, 16651-16657.

544 (17) (a) Kato, R.; Kobayashi, A.; Sasaki, Yu. 1:14 Heteropolyvana545 date of phosphorus: preparation and structure. J. Am. Chem. Soc. 1980, 546 102, 6571-6572. (b) Kato, R.; Kobayashi, A.; Sasaki, Yu. The 547 heteropolyvanadate of phosphorus. Crystallographic and NMR studies. 548 Inorg. Chem. 1982, 21, 240-246.

549 (18) Bakri, R.; Booth, A.; Harle, G.; Middleton, P. S.; Wills, C.; 550 Clegg, W.; Harrington, R. W.; Errington, R. J. Rational addition of 551 capping groups to the phosphomolybdate Keggin anion $\left[\mathrm{PMo}_{12} \mathrm{O}_{40}\right]^{3-}$ 552 by mild, non-aqueous reductive aggregation. Chem. Commun. 2012, 48, $5532779-2781$.
(19) Sha, J. Q.; Peng, J.; Tian, A. X.; Liu, H. S.; Chen, J.; Zhang, P. P.; 554 $\mathrm{Su}, \mathrm{Z}$. M. Assembly of Multitrack $\mathrm{Cu}-\mathrm{N}$ Coordination Polymeric 555 Chain-Modified Polyoxometalates Influenced by Polyoxoanion Cluster 556 and Ligand. Cryst. Growth Des. 2007, 7, 2535-2541.

(20) (a) Lehmann, J.; Gaita-Ario, A.; Coronado, E.; Loss, D. Spin 558 qubits with electrically gated polyoxometalate molecules. Nat. 559 Nanotechnol. 2007, 2, 312-317. (b) Long, D.-L.; Tsunashima, R.; 560 Cronin, L. Polyoxometalates: building blocks for functional nanoscale 561 systems. Angew. Chem., Int. Ed. 2010, 49, 1736-1758.

562

(21) Son, J.-H.; Ohlin, C. A.; Larson, E. C.; Yu, P.; Casey, W. H. 563 Synthesis and Characterization of a Soluble Vanadium-Containing 564 Keggin Polyoxoniobate by ESI-MS and ${ }^{51} \mathrm{~V}$ NMR: 565 (TMA) ${ }_{9}\left[\mathrm{~V}_{3} \mathrm{Nb}_{12} \mathrm{O}_{42}\right] \cdot 18 \mathrm{H}_{2} \mathrm{O}$. Eur. J. Inorg. Chem. 2013, 2013, 566 $1748-1753$.

(22) Guo, G.; Xu, Y.; Cao, J.; Hu, C. An unprecedented 568 vanadoniobate cluster with 'trans-vanadium' bicapped Keggin-type 569 $\left\{\mathrm{VNb}_{12} \mathrm{O}_{40}(\mathrm{VO})_{2}\right\}$. Chem. Commun. 2011, 47, 9411-9413.

570

(23) Shen, J.-Q.; Zhang, Y.; Zhang, Z.-M.; Li, Y.-G.; Gao, Y.-Q.; 571 Wang, E.-B. Polyoxoniobate-based 3D framework materials with 572 photocatalytic hydrogen evolution activity. Chem. Commun. 2014, 50, 573 6017-6019.

(24) Huang, P.; Zhou, E.-L.; Wang, X.-L.; Sun, C.-Y.; Wang, H.-N.; 575 Xing, Y.; Shao, K.-Z.; Su, Z.-M. New heteropolyniobates based on a 576 bicapped Keggin-type $\left\{\mathrm{VNb}_{14}\right\}$ cluster with selective adsorption and 577 photocatalytic properties. CrystEngComm 2014, 16, 9582-9585. 578

(25) Hou, D.; Hagen, K. S.; Hill, C. L. Pentadecavanadate, $\mathrm{V}_{15} \mathrm{O}_{42}{ }^{9-}$, 579 a new highly condensed fully oxidized isopolyvanadate with kinetic 580 stability in water. J. Chem. Soc., Chem. Commun. 1993, 0, 426-428. 581

(26) (a) Rooksby, H. P.; White, E. A. D. The structures of 1:1 582 compounds of rare earth oxides with niobia and tantala. Acta 583 Crystallogr. 1963, 16, 888-890. (b) Yoshida, S.; Nishimura, Y.; 584 Tanaka, T.; Kanai, H.; Funabiki, T. The local structures and photo- 585 catalytic activity of supported niobium oxide catalysts. Catal. Today 586 1990, 8, 67-75.

(27) Tsunekawa, S.; Kamiyama, T.; Sasaki, K.; Asano, H.; Fukuda, T. 588 Precise structure analysis by neutron diffraction for $\mathrm{RNbO} 4$ and 589 distortion of $\mathrm{NbO} 4$ tetrahedra. Acta Crystallogr., Sect. A: Found. 590 Crystallogr. 1993, A49, 595-600.

(28) Fulle, K.; McMillen, C. D.; Sanjeewa, L. D.; Kolis, J. W. 592 Hydrothermal Chemistry and Growth of Fergusonite-type $\mathrm{RENbO}_{4} 593$ $(\mathrm{RE}=\mathrm{La}-\mathrm{Lu}, \mathrm{Y})$ Single Crystals and New Niobate Hydroxides. Cryst. 594 Growth Des. 2016, 16, 4910-4917.

(29) Subramanian, M. A.; Aravamudan, G.; Rao, G. V. S. Oxide 596 pyrochlores-A review. Prog. Solid State Chem. 1983, 15, 55-143. 597 (30) Lv, Y.; Willkomm, J.; Leskes, M.; Steiner, A.; King, T. C.; Gan, 598 L.; Reisner, E.; Wood, P. T.; Wright, D. S. Formation of Ti28Ln 599 Cages, the Highest Nuclearity Polyoxotitanates $(\mathrm{Ln}=\mathrm{La}, \mathrm{Ce})$. Chem. -600 Eur. J. 2012, 18, 11867-11870.

(31) Hardcastle, F. D.; Wachs, I. E. Determination of niobium- 602 oxygen bond distances and bond orders by Raman spectroscopy. Solid 603 State Ionics 1991, 45, 201-213. 